Journal of Social Sciences 7 (4): 550-556, 2011

ISSN 1549-3652

(C) 2011 Science Publications

\title{
The Key Components of Job Satisfaction in Malaysian Water Utility Industry
}

\author{
${ }^{1}$ Khalizani Khalid, ${ }^{1}$ Hanisah Mat Salim, \\ ${ }^{1}$ Siew-Phaik Loke and ${ }^{2}$ Khalisanni Khalid \\ ${ }^{1}$ Department of Human Resource Management, \\ Universiti Teknologi MARA (UiTM) Perak, 32600, Bota, Perak, \\ ${ }^{2}$ Department of Chemistry, Faculty of Science, University of Malaya, \\ 50603 Kuala Lumpur, Malaysia
}

\begin{abstract}
Problem statement: This study aimed to examine the impacts of employee's rewards and employee's motivation on employee's job satisfaction between public and private water utility organization in Malaysia. Approach: A total of 689 employees from both sectors participated. While hierarchical regression analysis was conducted to test the relationship between employee's rewards, employee's motivation and employee's job satisfaction, gap analysis was utilized to determine the significant differences on the levels of employee's rewards, employee's motivation and employee's job satisfaction between both sectors. Results: The result revealed that (1) employee's reward was positively related to motivation; and (2) both employee's rewards and employee's motivation were found to had positive significant influences on employees' job satisfaction. The t-test result revealed that employees in public water utility organization scored significantly higher on the levels of employee's rewards, motivation and job satisfaction. Conclusion: The interesting findings showed that there are other factors than rewards and motivation involved in job satisfaction. However, motivation seems to give more impact to job satisfaction as compared to rewards for both organizations.
\end{abstract}

Key words: Water utility industry, employee's motivation, Work Preferences Inventory (WPI), organizations productivity, strategic intent

\section{INTRODUCTION}

High productivity and organizational performance could not be realized without the employee's support and contribution. This is because these human assets are largely responsible for the achievement of organization's vision, mission and goals. Selecting the right candidates and to effective develop them is a matter of great consequence for organization (Mehrdad, 2010). Therefore management should be concerned on issues and problems encountered by employees in the organization to ensure competitiveness. This study aims to compare the impact of employee's rewards and motivation on job satisfaction water utility industry in Malaysia. Water utility industry has been a monopoly industry in each state in Malaysia. In fact, the state government has decided to privatize their own water utility organization to increase organizations productivity to cater high public demands. Productivity of employees is derived from motivation stimulated by rewards offered by organizations to meet their job satisfaction (Okyere-Kwakye and Nor, 2011).
Organization performance is the pillar of success. However, success of each organization is supported by employee's job satisfaction towards the organization. If the organization could fulfil employees' satisfaction on job, automatically productivity will increase. To ensure that employees are satisfied with their job, they need to be motivated and compensate with rewards that are valued by the employees. Thus, this study can help the organizations to understand more on the link between motivation and linked organizational rewards in meeting employees' job satisfaction which then influence the organizational strategic intent (Azizi et al., 2009).

Employee's motivation levels are influenced by both intangible and tangible rewards. If rewards offered are not valued by the employees, it will affect their motivation. However, the level of employee's motivation is expected to rise if the rewards are valued by the employees to compensate their job performance. As a result, it is expected that the employee's motivation can drive the job satisfaction (Ramlall, 2004). 
Organizations required employees to perform in ways that lead to improved organizational performance. To satisfy the employees, tailored rewards packages are required to alter employee behaviour. The managers should be able to identify what is important to a person for job satisfaction and what can be offered in exchange for those desired behaviours. These factors need to be addressed by the organization to ensure rewards offered or provided could elicit employee's motivation and subsequently job satisfaction (Haque et al., 2006).

By identifying the link between rewards, motivation and job satisfaction, organizations could align their strategic intent with rewards offers to employees. Alignment between rewards and motivation is necessary as individual employee valued different types of rewards to increase their motivation to meet job satisfaction. Even though studies in the areas are plentiful, these relationships can be varied in specific industries particularly within government department. Thus, the aims of this research are twofold. First, investigating the relationship between employees' rewards, motivation and job satisfaction in public and private organization in water utility industry in Malaysia. Secondly, examined whether there is significant different on the levels of rewards, motivation and job satisfaction between private and public sectors employees.

\section{MATERIALS AND METHODS}

Stefanos and Dimitrios (2011) referred conceptual framework as a casual orientation toward the reflected study. Figure 1 presented the conceptual framework of this study to aid the comprehension and direction of this research. We proposed that the employees' job satisfaction is influenced by the rewards and motivation. And the employees' motivation is influenced by rewards offered by the employers.

Edwards et al. (2006) reported a correlation between rewards and motivation; and rewards and job satisfaction. Anna (2011) claimed that motivation is influenced by rewards and motivation correlated to job satisfaction. Fabian and Vesa (2011) mentioned that job satisfaction is influenced by rewards and motivation of employees. Milkovich et al. (2010)claimed that theories of motivation involved individual needs, reciprocation and behavior of employees. These elements are influenced by rewards to motivate job satisfaction. As shown in Fig. 1, the level of job satisfaction in public and private water utility industry is dependent on the linking of employees' level of motivation and the rewards offered by the organizations.

The model was proposed by Timothy et al. (2010) that suggested that job satisfaction was influenced by both intrinsic and extrinsic needs. Therefore, the level of job satisfaction in both organizations is dependent on the linking of individual needs and the rewards offered by the organizations to satisfy those needs.

Amabile et al. (1994) developed Work Preferences Inventory (WPI) to assess the individual perception differences in the degree of intrinsically and extrinsically motivated in their workplace. The degrees of intrinsic and extrinsic motivation of employees were used to evaluate the effects of rewards towards job satisfaction. The theory also suggested that intrinsic and extrinsic rewards stimulated intrinsic and extrinsic motivation respectively to increase employees' productivity and performance towards their job.

Edwards et al. (2006) suggested that rewards must be existed and met in the environment and job before an individual could be motivated to accomplish work. This match of rewards factors would allow an organization to implement the motivational efforts designed to improve performance. This theory assumed that efforts would lead to favourable performance and reward. This theory also used to indicate and predict job satisfaction and also suggested that people valued fair treatment which caused them to be motivated to keep the fairness maintained with the relationships of their co-workers and the organizations. Employees' job satisfaction would be achieved if employees were rewarded based on their contributions.

These elements influenced by rewards to motivate job satisfaction. As shown in Fig. 1, the level of job satisfaction in both organizations is dependent on the linking of employees' level of motivation and the rewards offered by the organizations. Therefore:

$\mathrm{H}_{1}=$ There is a positive relationship between employees' rewards and motivation

$\mathrm{H}_{2}=$ There is a positive relationship between employees' motivation and job satisfaction

$\mathrm{H}_{3}=$ There is a positive relationship between employees' rewards and job satisfaction

This study focuses on the Malaysia states water utility organizations since it is consisted of public and private entities. A simple random population of 689 water utility employees was selected. 


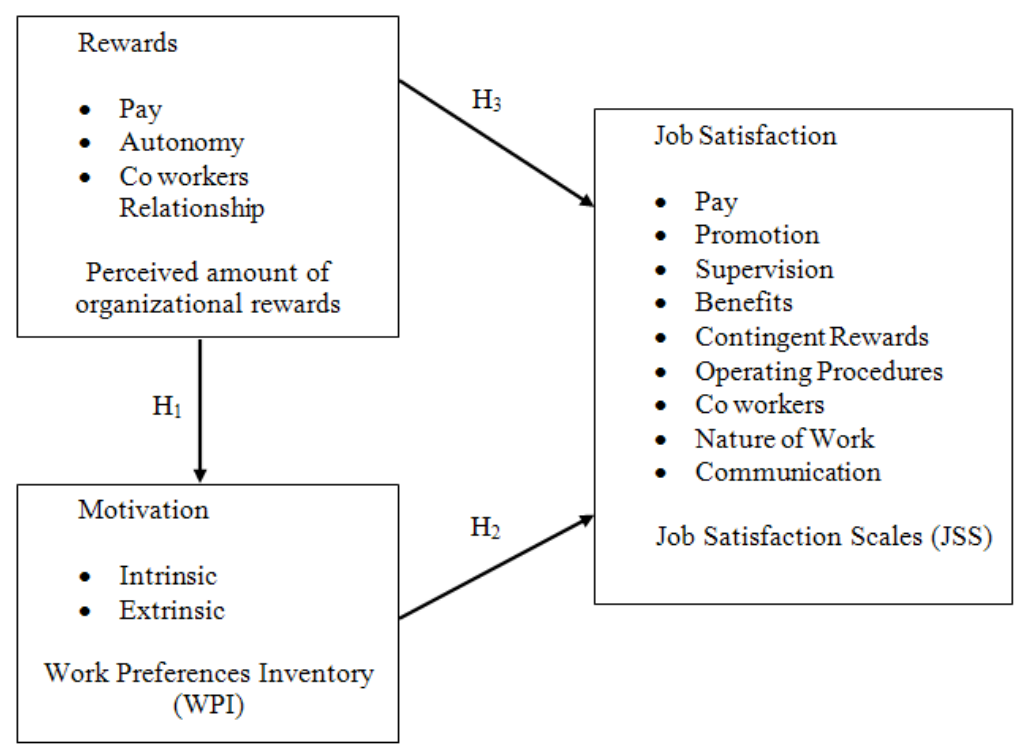

Fig. 1: Research framework

Demographic data such education background, employees' department, gender, length or service, position and age are collected as well. A list wise deletion was performed by SPSS to yield 351 completed and useable surveys. These respondents came from regional offices operated by organization across the states. The sample included 53 percent male, 47 percent female, 37 percent were aged between 25 to 34,40 percent had upper secondary school certificate and 26 percent has been working for 3-4 years.

\section{RESULTS}

Out of a maximum score of five, rewards, motivation and job satisfaction had a mean value of 3.45 , 3.45 and 3.24 respectively. This suggested that public and private sectors employees are moderately rewarded, motivated and satisfy in their jobs. Table 1 presents the means and standard deviations of the study variables.

Table 2 suggests that three facets of rewards had a significant correlations $(p<0.05)$ with motivation. All facets of rewards and motivation also had a significant correlations $(p<0.05)$ with all facets of job satisfaction.

A hierarchical regression was performed to evaluate the effects of covariates to independent variables via controlling the influence of education background, employees' department, gender, length or service, position and age group.

Hypothesis 1 is accepted since rewards was found to have a significant positive relationship with motivation $(\beta=0.71, \mathrm{p}<0.05)$ in water utility industry.
The addition of education background, employees' department, gender, length or service, position and age group significantly improved on the prediction by rewards, explaining 49 percent additional variance. The predicted relationship between employees' rewards and motivation was confirmed in this study for $\mathrm{H}_{1 \text { Public }}$ and $\mathrm{H}_{1 \text { Private }}$ in addition of education background, employees' department, gender, length or service, position and age group. Additional variance of 53 percent and 41 percent of employees' rewards was explained by motivation for $\mathrm{H}_{1 \text { Public }}(\beta=0.73, \mathrm{p}<0.05)$ and $\mathrm{H}_{\text {Private }}(\beta=0.65, \mathrm{p}<0.05)$ respectively. Thus, both hypotheses were supported. The breakdown of the result is tabulated in Table 3.

Table 4 showed that Hypothesis 2 of this study proposed that education background, employees' department, gender, length or service, position and age group were found to be significant predictors of job satisfaction for both public and private water utility organizations $(\beta=0.62, p<0.05)$. Additional variance of 46 percent of employees' motivation was explained by job satisfaction.

The predicted relationship between employees' motivation and job satisfaction was found in this study. $\mathrm{H}_{2 \text { Public }}(\beta=0.63, \mathrm{p}<0.05)$ variance added for 48 percent and $\mathrm{H}_{2 \text { Private }}(\beta=0.60, p<0.05)$ added for 36 percent of employees' motivation that explained by job satisfaction. As a result, $\mathrm{H}_{2 \text { Public }}$ and $\mathrm{H}_{2 \text { Private }}$ supported $\mathrm{H}_{2}$ in this analysis. 
Table 1: Means scores and standard deviations of study variables

\begin{tabular}{lll}
\hline Variables & Mean & Standard deviation \\
\hline Rewards & 3.45 & 0.58 \\
Motivation & 3.45 & 0.50 \\
Job Satisfaction & 3.24 & 0.45 \\
\hline
\end{tabular}

Table 2: The Pearson's correlation coefficients for the studied variables

\begin{tabular}{|c|c|c|c|c|c|c|c|c|c|c|c|c|c|}
\hline & & 1 & 2 & 3 & 4 & 5 & 6 & 7 & 8 & 9 & 10 & 11 & 12 \\
\hline 1 & JS_Pay & & & & & & & & & & & & \\
\hline 2 & JS_Promotion & $0.60^{*}$ & & & & & & & & & & & \\
\hline 3 & JS_Supervision & $0.56^{*}$ & $0.42^{*}$ & & & & & & & & & & \\
\hline 4 & JS_Benefits & $0.67^{*}$ & $0.64^{*}$ & $0.46^{*}$ & & & & & & & & & \\
\hline 5 & JS_Rewards & $0.68^{*}$ & $0.37^{*}$ & $0.60^{*}$ & $0.48^{*}$ & & & & & & & & \\
\hline 6 & JS Coworkers & $0.47^{*}$ & $0.31^{*}$ & $0.59^{*}$ & $0.47^{*}$ & $0.46^{*}$ & & & & & & & \\
\hline 7 & JS_Nature & $0.62^{*}$ & $0.53^{*}$ & $0.66^{*}$ & $0.52^{*}$ & $0.45^{*}$ & $0.50^{*}$ & & & & & & \\
\hline 8 & JS_Communication & $0.37^{*}$ & $0.43^{*}$ & $0.41^{*}$ & $0.37^{*}$ & $0.27^{*}$ & $0.33^{*}$ & $0.48^{*}$ & & & & & \\
\hline 9 & Rew_Pay & $0.47^{*}$ & $0.52^{*}$ & $0.28^{*}$ & $0.48^{*}$ & $0.27^{*}$ & $0.22^{*}$ & $0.43^{*}$ & $0.56^{*}$ & & & & \\
\hline 10 & Rew Autonomy & $0.50^{*}$ & $0.58^{*}$ & $0.39^{*}$ & $0.45^{*}$ & $0.30^{*}$ & $0.33^{*}$ & $0.52^{*}$ & $0.59^{*}$ & $0.75^{*}$ & & & \\
\hline 11 & Rew_Coworkers & $0.37^{*}$ & $0.43^{*}$ & $0.41^{*}$ & $0.37^{*}$ & $0.27^{*}$ & $0.33^{*}$ & $0.48^{*}$ & $1.00^{*}$ & $0.56^{*}$ & $0.59^{*}$ & & \\
\hline 12 & Mot Intrinsic & $0.44^{*}$ & $0.42^{*}$ & $0.46^{*}$ & $0.45^{*}$ & $0.34^{*}$ & $0.36^{*}$ & $0.47^{*}$ & $0.58^{*}$ & $0.50^{*}$ & $0.52^{*}$ & $0.58^{*}$ & \\
\hline 13 & Mot_Extrinsic & $0.44^{*}$ & $0.42^{*}$ & $0.46^{*}$ & $0.45^{*}$ & $0.34^{*}$ & $0.36^{*}$ & $0.47^{*}$ & $0.58^{*}$ & $0.50^{*}$ & $0.52^{*}$ & $0.58^{*}$ & $1.00^{*}$ \\
\hline
\end{tabular}

Notes: $\mathrm{N}=351,{ }^{*}$ Correlation is significant at the 0.05 level ( 2 tailed)

Table 3: Hierarchical regression analysis between rewards and

\begin{tabular}{llll}
\multicolumn{1}{c}{ motivation } & & & \\
\hline Variables & $\mathrm{H}_{1}{ }^{\S}$ & $\mathrm{H}_{1 \text { Public }}$ & $\mathrm{H}_{1 \text { Private }}$ \\
\hline Rewards & $0.000^{* *}$ & $0.000^{* *}$ & $0.000^{* *}$ \\
Model 1 R & 0.03 & 0.06 & 0.01 \\
Model 2 $\mathrm{R}^{2}$ & 0.49 & 0.53 & 0.41 \\
$\beta$ Rewards & 71.0 & 73.0 & 65.0 \\
\hline
\end{tabular}

Note: ${ }^{\S}$ Both Employees from Public and Private Sector $* *$ significant at $p<0.05$

Table 4: Hierarchical regression analysis between motivation and job

\begin{tabular}{llll}
\multicolumn{1}{c}{ satisfaction } & & & \\
\hline Variables & $\mathrm{H}_{2}$ & $\mathrm{H}_{2 \text { Public }}$ & $\mathrm{H}_{2 \text { Private }}$ \\
\hline Motivation & $0.000^{* *}$ & $0.000^{* *}$ & $0.000^{* *}$ \\
Model 1 R & 0.09 & 0.11 & 0.01 \\
Model 2 $\mathrm{R}^{2}$ & 0.46 & 0.48 & 0.36 \\
$\beta$ Motivation & 62.0 & 63.0 & 60.0
\end{tabular}

Note: $* *$ Significant at $p<0.05$

Table 5: Hierarchical regression analysis between rewards and job satisfaction

\begin{tabular}{llll}
\hline Variables & $\mathrm{H}_{2}$ & $\mathrm{H}_{2 \text { Public }}$ & $\mathrm{H}_{2 \text { Private }}$ \\
\hline Rewards & $0.000^{* *}$ & $0.000^{* *}$ & $0.000^{* *}$ \\
Model 1 R & 0.09 & 0.11 & 0.01 \\
Model 2 $\mathrm{R}^{2}$ & 0.38 & 0.37 & 0.31 \\
$\beta$ Rewards & 56.0 & 55.0 & 57.0 \\
\hline
\end{tabular}

Note: ** Significant at $p<0.05$

Table 5 represented that there is a positive significant relationship between employees' rewards and job satisfaction in both public and private water utility organizations $(\beta=0.56, \quad \mathrm{p}<0.05)$, thus Hypothesis 3 is accepted. The addition of education background, employees' department, gender, length or service, position and age group significantly improved on the prediction by rewards, explaining 38 percent additional variance.
Table 6: Comparison between public and private water utility organizations

\begin{tabular}{lllll}
\hline & Water & & & \\
& Utility & & Standard & \\
Variables & Organization & Means & Deviations & $t$ \\
\hline Rew_Pay & Public & 3.44 & 0.65 & $3.56^{*}$ \\
& Private & 3.20 & 0.62 & \\
Rew_Autonomy & Public & 3.65 & 0.62 & $5.55^{*}$ \\
& Private & 3.29 & 0.57 & \\
Rew_Coworkers & Public & 3.70 & 0.72 & $3.90^{*}$ \\
& Private & 3.40 & 0.75 & \\
Mot_Intrinsic & Public & 3.51 & 0.54 & $3.51^{*}$ \\
& Private & 3.31 & 0.52 & \\
Mot_Extrinsic & Public & 3.51 & 0.54 & $3.51^{*}$ \\
& Private & 3.31 & 0.52 & \\
JS_Pay & Public & 3.45 & 0.60 & $8.43^{*}$ \\
JS_Promotion & Private & 2.93 & 0.54 & \\
& Public & 3.21 & 0.64 & $4.03^{*}$ \\
JS_Supervision & Private & 2.96 & 0.51 & \\
& Public & 3.63 & 0.57 & $9.04^{*}$ \\
JS_Benefits & Private & 3.13 & 0.46 & \\
& Public & 3.25 & 0.66 & $5.93^{*}$ \\
JS_Rewards & Private & 2.88 & 0.48 & \\
& Public & 3.30 & 0.65 & $6.64^{*}$ \\
JS_Coworkers & Private & 2.89 & 0.51 & \\
JS_Nature & Public & 3.61 & 0.52 & $9.46^{*}$ \\
JS_Communication & Private & 3.11 & 0.46 & \\
& Public & 3.68 & 0.54 & $7.81^{*}$ \\
& Private & 3.26 & 0.45 & \\
& Public & 3.70 & 0.72 & $3.90^{*}$ \\
& Private & 3.40 & 0.75 & \\
\hline
\end{tabular}

Note: "Significant at $\mathrm{p}<0.05$

Table 6 provided the means, standard deviation and $\mathrm{t}$ value for the analysis. There were significant differences for public and private water utility organizations in the level of employees' rewards, motivation and job satisfaction. Employees from public water utility organization perceived that their organization emphasized more on rewards and motivation towards employees' job satisfaction in comparison to private water utility organization. 

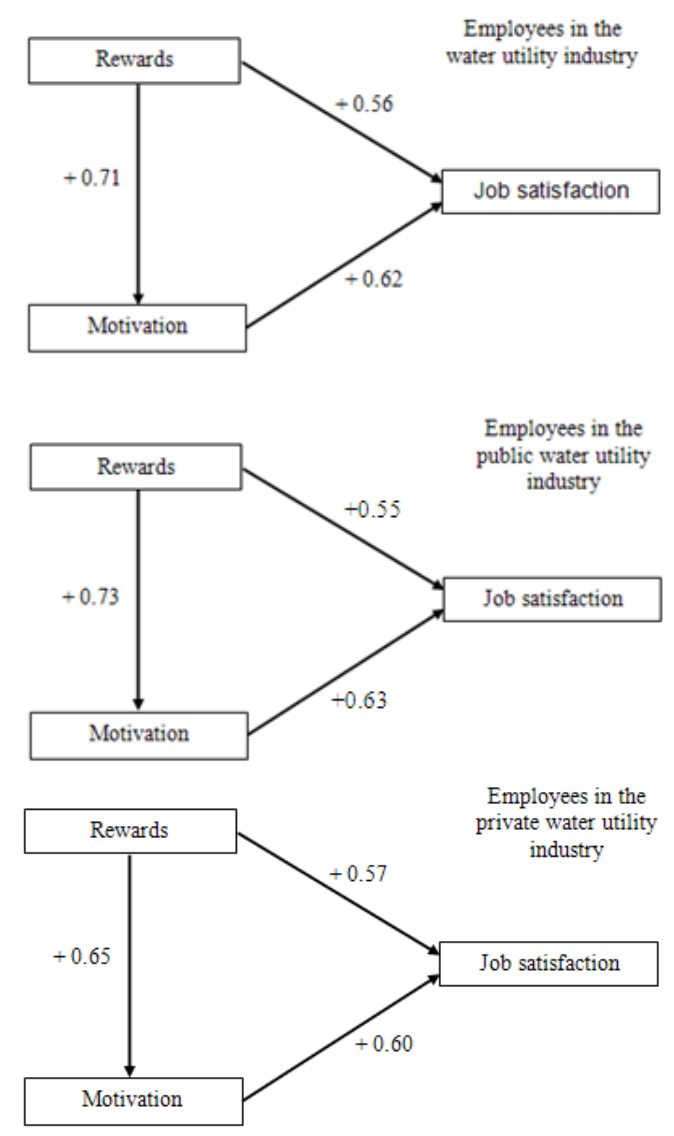

Fig. 2: Comparing the relationships of reward, motivation and job satisfaction for employees in the water utility industry

The predicted relationship between employees' motivation and job satisfaction was found in this study. After controlling the factors of education background, employees' department, gender, length or service, position and age group, we found that $\mathrm{H}_{3 \mathrm{Public}}(\beta=0.55$, $\mathrm{p}<0.05)$ and $\mathrm{H}_{3 \text { Private }}(\beta=0.57, \mathrm{p}<0.05)$ were supported with additional variance of 37 percent and 31 percent of employees' rewards that explained by job satisfaction. Figure 2 illustrated the comparison in the relationships of reward, motivation and job satisfaction for employees in the water utility industry.

\section{DISCUSSION}

Aligned with the literature, the degree of rewards, motivation and job satisfaction of private water utility employees was found significantly lower than in public sector. (Ramlall, 2004; Chiu et al., 2002) implied that rewards improves employees motivation. According to
(Bajpai and Srivastava, 2004) public employees were offered with pension, security and other welfare policies compared to private employees. This resulted 48 percent of variance in motivation was explained by rewards in water utility industry. If motivation is increased, the incremental variances in employees' rewards for public and private water utility organizations were 51 percent and 38 percent respectively.

Yang (2010) suggested that job satisfaction is an important motivator for employee's performance. Zaini et al. (2009) implied job satisfaction will lead to different behaviors that arise from different types of motivation. 39 percent and 35 percent of variance in job satisfaction for public and private employees was explained by motivation. It shows that motivation influenced public employees more than to private employees. This result consistent with study by Luthans and Sommers (2005) that indicated, high motivation was influenced by high rewards offered to the employees by public sector organizations.

Terry (2010) proposed job satisfaction is not linked to the absolute amount of pay. Hartog and Verburg (2004) mentioned that experience satisfaction derived from fair and just manner rewards decision making by the organizations. The result showed that 28 percent and 33 percent of variance in job satisfaction was explained by rewards for public and private water utility organziations respectively. This result supported argument by (Zaini et al., 2009; Chew, 2005; Kiviniemi et al., 2002; Ramlall, 2004) that claimed private sector managers place greater value on economic rewards.

According to Linz and Semykina (2007), organizations that emphasized on autonomy and co workers relationship will experience high employees' job satisfaction. Autonomy received must equal to extrinsic rewards offered to employees. Jonathan and Evan (2009) added that competitive advantage among private water utility organization can be increased if employees are motivated extrinsically via providing extrinsic rewards to increase their job satisfaction. Bajpai and Srivastava (2004) noted that public organizations made an effort to offer more extrinsic rewards to increase extrinsic motivation of public employees. This is important as public water utility employees are served with different objectives to meet public demands. Thus, rewards must be realigned to strategically fit the organization objectives to boost employees' motivation to perform well and satisfy with the jobs. Fey et al. (2009) indicated that linking employee participation results in greater productivity, satisfaction and reduction in turnover. This result signifies that different entity status perceived 
different level of rewards and motivation towards job satisfaction.

\section{CONCLUSION}

The findings of the demographic based research questions are consistent with much of the recent academic literature regarding employees' rewards, motivation and job satisfaction. Thus, this demographic information is useable to explore the relationship of age group, gender, level of education and length of service on rewards, motivation and job satisfaction perceived by each demographic variable. The result of this study will facilitate the water utility organizations or other organizations to establish or improvise their rewards packages as a motivator to increase their motivation to achieve job satisfaction.

The study provided empirical evidence to better understand the rewards, motivation and job satisfaction factors involved in the study. This study identified the relationship between employees' rewards, motivation and job satisfaction and its significant difference between public and private water utility industry. As indicated by the result, employees' rewards (pay, autonomy and co workers relationship) and motivation (extrinsic and intrinsic) were not the only factors for job satisfaction in both sectors.

Findings suggested that there are other factors than rewards and motivation involved in job satisfaction. Overall, both water utility organizations employees reported that they accept moderately that rewards stimuli motivation. Moreover, even though employees' rewards and motivation are moderately considered as job satisfaction factors, however, motivation seems to give more impact to job satisfaction as compared to rewards for both organizations. Acceptance level of rewards, motivation and job satisfaction between public sector and private sector in water utility industry were aligned with earlier findings as both organizations perceived different level of rewards to increase motivation as well as perceived different level of rewards and motivation for job satisfaction.

This result signifies that employees from different entity status perceived levels of rewards and motivation towards job satisfaction differently. This study provides greater understanding to the potential impact of organizational status (public or private organization) on the perceived level of rewards, motivation and job satisfaction and how to better incorporate employees' rewards with motivation while continuing to address the concerns of employees' job satisfaction in water utility industry.

\section{REFFERENCES}

Amabile, T.M., K.G. Hill, B.A. Hennessey and E.M. Tighe, 1994. The Work Preferences Inventory: Assessing intrinsic and extrinsic motivational orientations. J. Person. Soc. Psychol., 66: 950-967. DOI: 10.1037/0022-3514.66.5.950

Anna, M.Z., 2011. Relationships between anxiety and job satisfaction-three approaches: 'Bottom-up' 'top-down' and 'transactional'. Pers. Indiv. Differ., 50: 977-986. DOI: 10.1016/j.paid.2010.10.013

Azizi, Y., Y. Noordin, A. Kamariah, I. Jasmi and J. Saini et al., 2009. Occupational stress and its effects towards the organization management $\mathrm{J}$. Soc. Sci., 5: 390-397. DOI: 10.3844/jssp.2009.390.397

Bajpai, N. and D. Srivastava, 2004. Sectorial comparison of factors influencing job satisfaction in Indian banking sector. Singapore Manage. Rev., 26: 89-99.

Chew, Y.T., 2005. Achieving organizational prosperity through employee motivation and retention: A comparative study of strategic HRM practices in Malaysian institutions. Res. Practice Hum. Resource Manage., 13: 87-104.

Chiu, R.K., V.W-M. Luk and T.L-P. Tang, 2002. Retaining and motivating employees: Compensation preferences in Hong Kong and China. Person. Rev., 31: 402-431. DOI: 10.1108/00483480210430346

Edwards, J., D.M. Cable, I.O. Williamson, L.S. Lambert and A.J. Shipp, 2006. The phenomenology of fit: linking the person and environment to the subjective experience of person-environment fit. J. Applied Psychol., 91: 802-827. DOI: 10.1016/S0021-9010(06)61894-3

Fabian, J.F. and P. Vesa, 2011. Cultural distance and expatriate job satisfaction. Int. J. Intercult. Relat., 35: 49?60. DOI: 10.1016/j.ijintrel.2010.10.002

Fey, C.F., S. Morgulis-Yakushev, H.J. Park and I. Bjorkman, 2009. Opening the black box of the relationship between HRM practices and firm performance: A comparison of MNC subsidiaries in the USA, Finland and Russia. J. Int. Bus. Studies 40: 690-712. DOI: 10.1057/JIBS.2008.83

Haque, A., A. Khatibi and K. Karim, 2006. Reorganization impact on the telekom malaysia?s international division productivity. J. Soc. Sci., 2: 35-40. DOI: $10.3844 /$ jssp.2006.35.40 
Hartog, D.N.D. and R.M. Verburg, 2004. High performance work systems, organizational culture and firm effectiveness. Hum. Resource Manage. J., 14: $\quad 55-78$. DOI: $\quad 10.1111 / \mathrm{j} .1748-$ 8583.2004.tb00112.x

Jonathan, P.W. and M.B. Evan, 2009. Job satisfaction of public managers in special districts. Rev. Publ. Person. Admin., 29: 327-353. DOI: 10.1177/0734371X09337710

Kiviniemi, M.T., M. Snyder and A.M. Omoto, 2002. Too many good thing? The effect of multiple motivations on stree, cost, fulfillment and satisfaction. Person. Soc. Psychol. Bull., 28: 732743. DOI: $10.1177 / 0146167202289003$

Linz, J.S. and A. Semykina, 2007. How do workers fare during transition? Perceptions of job insecurity among Russian workers, 1995-2004. Labour Econ., 15: 442-458. DOI: 10.1016/j.labeco.2007.05.003

Luthans, K.W. and S.M. Sommers, 2005. The impact of high performance work on industry level outcomes. J. Manage. Issue., 17: 327-345.

Mehrdad, G.C., 2010. The relationship between organizational culture and staff productivity public organizations. J. Soc. Sci., 6: 127-129. DOI: 10.3844/jssp.2010.127.129

Milkovich, J.M. Newman, B.A. Gerhart, 2010. Compensation. 10th Edn., McGraw-Hill Irwin, New York, ISBN: 0071289453, pp: 672..

Okyere-Kwakye, E and M.K. Nor, 2011. Individual factors and knowledge sharing. Am. J. Econ. Bus. Admin., 3: 66-72. DOI: 10.3844/ajebasp.2011.66.72
Ramlall, S., 2004. A review of employee motivation theories and their implications for employee retention within organizations. J. Am. Acad. Bus., 5: 52-64.

Stefanos, K.G. and M.M. Dimitrios, 2011 Modelling job satisfaction in low-level jobs: Differences between full-time and part-time employees in the Greek retail sector. Eur. Manage. J., 29: 129-143. DOI: 10.1016/j.emj.2010.12.002

Terry, T.I., 2010. Exploring the effects of congruence and Holland's personality codes on job satisfaction: An application of hierarchical linear modeling techniques. J. Vocat. Behav., 76: 16-24. DOI: 10.1016/j.jvb.2009.06.014

Timothy, A.J., F.P. Ronald, P.P. Nathan, C.S. John and L.R. Bruce, 2010. The relationship between pay and job satisfaction: A meta-analysis of the literature. J. Vocat. Behav., 77: 157-167. DOI: 10.1016/j.jvb.2010.04.002

Yang, J-T., 2010. Antecedents and consequences of job satisfaction in the hotel industry. Int. J. Hosp. Manag. 29: 609-619. DOI: 10.1016/j.ijhm.2009.11.002

Zaini, A., A. Nilufar and S.A. Syed, 2009. The effect of human resource management practices on business performance among private companies in Malaysia. Int. J. Bus. Manag., 4: 65-72. 